УДК881.111(076)

DOI: 10.17277/voprosy.2017.04.pp.173-180

\title{
EXPANDING ACADEMIC VOCABULARY THROUGH LOGICAL GAMES
}

\section{B. Korotkina}

Moscow School of Social and Economic Sciences, Moscow, Russia

Reviewed by Doctor of Pedagogic Sciences, Professor R. P. Milrood

Keywords: academic literacy; academic vocabulary; course design; English for Specific Academic Purposes.

\begin{abstract}
Academic literacy and writing involves mastering not only rhetoric and text-building, but also academic vocabulary skills. The corpus of the English academic vocabulary mainly consists of words from classical languages, the frequency of which is much higher in the academic language than vernacular, sometimes limiting the number of native words to articles and prepositions. Another peculiarity of the adoptions is word formation through affixation, which is not common in contemporary English, but quite common in Russian. This similarity provides a perfect opportunity for Russian students to boost their English academic vocabulary actively and productively. The only effort needed is that of the course designer. Academic Vocabulary for Social Sciences (HSE Publishing House, 2016) is the course that motivates postgraduate students and researchers to work collaboratively, applying their background knowledge and analytic skills to challenging tasks presented through specific PowerPoint-based learning environment. This approach, visualized methodologically as an uprising evolving spiral, provides learners with strategies applicable in their further professional development. Approbated in two universities, it can be of interest to EAP teachers working in postgraduate education and professional development programmers.
\end{abstract}

\section{Introduction}

Although researchers need specific language to keep on with proceedings in their discipline and write research papers in English, most vocabulary problems they encounter are transdisciplinary. The register frequently depends

Короткина Ирина Борисовна - кандидат педагогических наук, доцент, заведующая кафедрой английского языка, e-mail: irina.korotkina@gmail.com, ОАНО ВО «Московская высшая школа социальных и экономических наук», г. Москва, Россия.

УНИВЕРСИТЕТ им. В.И. ВЕРНАДСКОГО. №4(66). 2017. 
on the origin of the word because in metaphoric context (which is common in academic texts), words of Latin or Greek origin are most preferable. Classical languages are only seemingly defunct, for their elements are widely (and internationally) used to form new disciplinary terms, and welcomed by website creators to attract educated audience. The English corpus in general contains around 70 per cent of words from classical languages, but academic English tends to sometimes apply them up to 100 per cent, if articles, auxiliaries and prepositions are not taken into consideration. Moreover, words from classical languages live their own lives in English, following their own rules of word formation, spelling and pronunciation - a good prompt for a teacher to make use of them. Therefore, this powerful corpus appears to be particularly useful in teaching EAP and ESP.

The course Academic Vocabulary for Social Sciences was designed through a dozen of years of classroom experiments to provide postgraduate students with a specific skill set which would enable them not only to cope with unknown words, but also to build new ones. It was conceived and developed for postgraduate students of the Moscow School of Social and Economic Sciences a Russian-British university, and later successfully approbated in professional development programmes for researchers and academics at the National Research University Higher School of Economics. Eventually, it was designed into a course book and published by the HSE Publishing House (Korotkina, 2016). In this paper I will briefly describe the innovative approach used in the course and the key elements that helped organize its content in a specific didactic way, which proved efficacious both with students and academics.

\section{Approaches to Teaching Academic Vocabulary}

Academic vocabulary is not commonly taught as a separate EAP course, but rather integrated into other courses along with grammar support. In course books, it usually takes the form of controlled practice exercises, which precede or follow the main reading or writing task and introduce or revise the selection of words relevant for the text or topic. There are also specialized books on academic vocabulary, but they are intended to either support reading and writing courses at university level (e.g. Campbell, 2009; McCarthy, M. \& O'Dell, 2008), or supplement international tests, such as SAT, IELTS or TOEFL (Bromberg, 2013; Cullen, 2008; Matthiesen, 2011). Because of that the tasks in them are typically constructed in repetitive (though various) sets of exercises, relevant for self-study or home assignments.

Despite the unquestionable importance of words from classical languages in forming international academic vocabulary and scientific terminology, books devoted to their functioning in English are scarce. Resources involving Latin word formation usually employ matching techniques in online resources or flash cards (Common Prefixes; Greek Roots; Lundquist \&Lundquist, 2003). They can generally be considered as supplementary to vocabulary course books, and therefore even more additional in usage than those. In fact, there are two books based on classical vocabulary, one by Levine (1965) and the other by Ayers, (1986), both written in the 1960s. This approach appears to have long 
been abandoned, although some teachers in the US use the books in their courses. However, more recent books on expanding academic vocabulary through Latin word formation have not appeared for nearly half a century.

Such neglect could be explained by the fact that affixation has virtually disappeared from contemporary English, and native speakers (and teachers among them) are not as familiar with this means of word formation as Russians are. Another reason may be that the audience of teaching academic English is widely international, and there are plenty of students whose languages do not even use word class at all (e.g. Chinese). On the contrary, in a monolingual Russian classroom word formation provides a remarkable tool for expanding students' academic vocabulary without having to memorize words or forgetting them in the future. As the books of the 1960s lack today's teaching methods, I thought it best to design a new course of my own.

\section{Academic Vocabulary Course Design}

The course Academic Vocabulary for Social Sciences was initially designed and taught as a specific course with the focus on vocabulary building, without reference to reading or writing. The unique approach that helped make the course motivating and enhancing incorporates three major components: employing Cummins's model of common underlying proficiency (CUP), the evolving spiral approach to developing language skills, and PowerPoint-based interactive activities (PIA).

According to the model of CUP, or dual iceberg model of language acquisition introduced by Jim Cummins (1996), students can actively involve into language learning the notions and concepts which are common in both L1 and L2. As academic words of classical origin are mainly international and preserve the same patterns of word formation across languages, they form the underlying lexical proficiency for both English and Russian. Involving interaction between the two corpuses through analogies, comparison and contrast, analysis and synthesis of common lexis, students develop the skills of (re)construction of previously unknown words. As words of Latin and Greek origin are mostly used in metaphoric, academic or other formal contexts, the common proficiency in this regard is more profound with adult learners whose academic background has been developed in higher education.

Another feature of the course the course employs the evolving spiral approach to developing language skills, designed and used by the team of teachers of the MSSES Interdisciplinary Department of English (Korotkina, 2011). The approach proved successful in different EAP/ESP contexts because it helps avoid direct repetition or memorizing and involves all the previously obtained skills into solving language problems of higher order. Applying the evolving spiral approach to analytic and logical tasks in the course of Academic Vocabulary for Social Sciences proved especially efficient in combination with the CUP model.

The third component of the course provides an entertaining visual context in which the described above approaches become even more motivating. It was in this course that PowerPoint-based interactive activities (PIA) were first 
designed (Korotkina, 2012), although later they were described as a more general technique. Animated words and affixes appear on the screen along with visual prompts, such as colour, font or images and follow students' collective logical conclusions or guesses. This bright and entertaining visual context enhances collaboration and the sense of achievement in each student regardless of one's particular abilities. It is an essentially facilitating technique, for the teacher virtually withdraws from the classroom, just clicking the key in the right minute and leaving the group interacting with the screen.

A good example of how the three components of the course work together is the task in which students are given words of Latin origin (e.g. 'aquatic', 'multicoloured', 'conference'), and have to find the appropriate lexical correspondences of Greek origin (respectively, 'hydraulic', 'polychromatic', 'symposium'). The words appear on the screen as soon as the right word is pronounced. However, as the task becomes more and more complicated (e.g. 'subscription' - 'hypograph'), it takes more and more intellectual effort on behalf of the group to come out with the right guess. Finally, when words on both sides of the screen are difficult to grasp ('Subterranea' - 'hypogaeum'), images of underground communications and an underground tomb appear. This technique prevents the teacher from direct explanations and provides the shortest and most effective way to understanding.

\section{Manual Design}

When the course was developed into a book, the problem was to arrange the activities so that it can be used not only in the classroom, but also for selfstudy. The tasks and activities in the book are organized according to the same principles in that the student's analytical skills and background knowledge are involved on the basis of gradual evolution. Unlike most vocabulary manuals, where exercises and tasks (although various) are arranged into sets of similar units, the book Academic Vocabulary for Social Sciences presents activities in three different parts, each of which has a different content with different, content-dependent activities.

Part I Do You Speak Ancient Greek? Words of Greek Origin in English introduces students into academic vocabulary of Hellenic origin. Such words cause problems mostly in spelling and pronunciation; activities aimed at developing these skills are therefore different from those aimed at developing word formation. The latter is presented in Part II Are You pro or con? Coping with Word Formation. This part deals with the meanings of particular prefixes, suffixes and endings (e.g. millennium - millennia, crisis - crises, formula formulae). Part III Lingua Latina, Lingua Franca. Expanding Vocabulary through Latin Roots involves all the previous skills in word deciphering and word formation organized around 20 Latin roots. As most Greek words have come into European languages through Latin, the spelling problems they cause occur throughout the book. The book also contains a pre-test to the course, revision sections with activities that depend on the content and skills being revised, the concluding section Three Farewell Activities, and an appendix.

The course book contains two books, the Student's Book with activities, instructions and illustrations, and the Teacher's Book with keys and guidelines and author's explanations. The explanations are given in Russian and address 


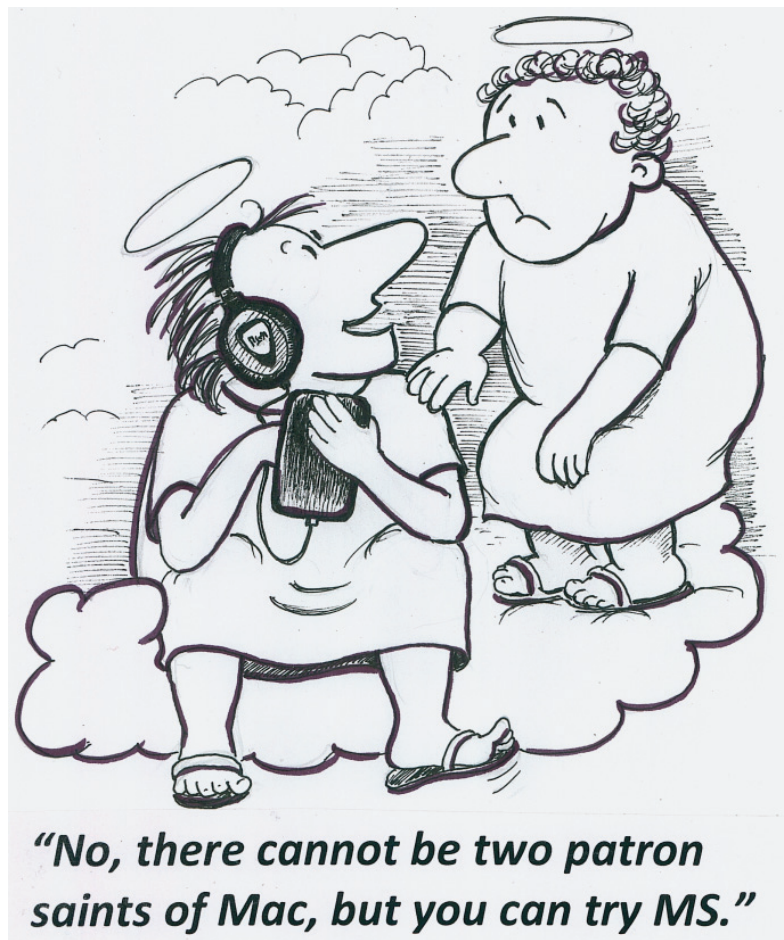

Fig. 1. An illustration to Part III Chapter 1.7 Repatriating Patriots (roots patr/pater)

the reader in a friendly and encouraging way. Although Russian is not used in the course as a language of instruction, it was relevant and appropriate to use it in the Teacher's Book to avoid multiple problems and misunderstandings in dealing with such a variety of different assignments and not always obvious ways of solving language problems.

It was also essential to incorporate the PIA into the course book. This was achieved by referring to the slides in the corresponding activities and giving a general reference to the PIA on the Publisher's and my own website (Interactive Slides). However, I took another effort to illustrate the book, drawing cartoons to some activities and the front cover (Fig. 1).

\section{Conclusion}

In EAP, especially ESAP (English for specific academic purposes), it is essential for teachers to design their own learning materials. Today, it becomes recognized among methodologists that the teacher's role in a particular classroom is much bigger than that of obediently delivering materials from a book (e.g. Kumaravadevelu, 2001). The course described in this paper and demonstrated in the workshop at the conference contributes to the idea. It has been successful in the classroom for over 15 years, the average mark in questionnaires in both universities pertaining over 9 on the 10-band scale.

It is also important to share good practice with other teachers, and while it might be enough in some cases to publish an article or give a workshop, it might in others take as much as writing a course book. Of course, writing 
books or drawing one's own illustrations is far not always necessary for a good teacher; however, designing and collecting one's own activities for particular groups of students should be regular practice for a creative teacher, bringing the sense of self-achievement, increasing the effectiveness of a particular course for the students, and last but not least, enhancing stronger relationship between teacher and students.

\section{Acknowledgements}

I gratefully acknowledge the invaluable support of Maria Yudkevich, the Vice Rector of the National Research University Higher School of Economics, in promoting my book for publication at the HSE Publishing House. I also express my gratitude to Zhenya Bakin, Director of the HSE Academic Writing Center, for the opportunity to approbate the course in a different educational context, and also Professor Ludmila Chikileva, Financial University under the Government of the RF, and Ludmila Kuznetsova, St. Petersburg State University, and for reviewing the book.

\section{References}

1. Ayers D.M. English Words from Latin and Greek Elements, USA: University of Arizona Press, 1986, 290 p.

2. Bromberg M. 1100 Words You Need to Know, Moscow: Barron's Educational Series, 2013, $408 \mathrm{p}$. $189 \mathrm{p}$.

3. Campbell C. English for Academic Study: Vocabulary, Reading: Garnet, 2009.

4. https://www.msu.edu/ defores1/gre/roots/gre_rts_afx $2 . h t m$

(accessed 10 February 2017).

5. Cullen P. Cambridge Vocabulary for IELTS, Cambridge: Cambridge University Press, 2008, $176 \mathrm{p}$.

6. Cummins J. Negotiating Identities: Education for empowerment in a diverse society, Los Angeles: California Association for Bilingual Education, 1996, 290 p.

7. http://www.infoplease.com/ipa/A0907013.html(accessed 10 February 2017).

8. http://korotkina.ru/publications/interactive_slides/ (accessed 10 February 2017).

9. Kumaravadivelu B. Toward a Postmethod Pedagogy, TESOL Quarterly, 2001, vol. 35 , no. 4 , pp. 537-560.

10. Levine H. Vocabulary for the College-Bound Student, New York: Amsco School Publications, 1965, 399 p.

11. Lundquist J.K., Lundquist J. L. English from the Roots Up Flashcards. Help for Reading, Writing, Spelling, and S.A.T. Scores. Medina, Washington: Literacy Unlimited Publications, 2003, $106 \mathrm{p}$.

12. Matthiesen S.J. Essential Words for the TOEFL, Moscow: Barron's Educational Series, 2011, $310 \mathrm{p}$.

13. McCarthy M., O’Dell F. Academic Vocabulary in Use. Cambridge: Cambridge University Press, 2008,176 p.

14. Korotkina I.B. Academic Vocabulary for Social Sciences. Moscow: HSE Publishing House, 2016, 302 p.

15. Korotkina I.B. [And again, PIA: the life of interactive materials in the course of academic vocabulary], Informatsionno-kommunikatsion nyete khnologii $v$ lingvistike, lingvodidaktik eimezhkul'turnoi kommunikatsii [Information and 
communication technologies in linguistics, linguodidactics and intercultural communication], Moscow: Universitetskaya kniga, 2012, no. 5, pp.372-379.(In Russ.)

16. Korotkina I.B. UMK «English for Public Administration»: pod"empospirali razvitiya professional'nykh i akademicheskikh yazykov ykh navykov ["English for Public Administration" Course book: The evolving spiral of language for professional and academic purposes], Proceedings All-Russian Scientific and Practical Conference «Teacher, student, textbook», 2011,pp. 85-90.(In Russ.)

\section{Список литературы}

1. Ayers, D. M. English Words from Latin and Greek Elements / D. M. Ayers. USA : University of Arizona Press, 1986. $-290 \mathrm{p}$.

2. Bromberg, M. 1100 Words You Need to Know / M. Bromberg. - M. : Ed. Barron's Educational Series, 2013. - 408 p.

3. Campbell, C. English for Academic Study: Vocabulary /C. Campbell. - Reading : Garnet, 2009. $-189 \mathrm{p}$.

4. Common Prefixes, Suffixes, and Root Words [Электронный ресурс]. - Режим доступа : https://www.msu.edu/ defores1/gre/roots/gre_rts_afx2.htm (дата обращения:10.02.2017).

5. Cullen, P. Cambridge Vocabulary for IELTS / P. Cullen.- Cambridge : Cambridge University Press, 2008. - 176 p.

6. Cummins, J. Negotiating Identities: Education for Empowerment in a Diverse Society / J. Cummins. - Los Angeles : California Association for Bilingual Education, 1996. $-290 \mathrm{p}$.

7. Greek Roots, Prefixes and Suffixes [Электронный pecypc]. - Режим доступа : http://www.infoplease.com/ipa/A0907013.html (дата обращения: 10.02.2017).

8. Korotkina, I. Interactive Slides (ПИУМы) [Электронный pecypc] / I. Korotkina. - Режим доступа : http://korotkina.ru/publications/interactive_slides/ (дата обращения: 10.02.2017).

9. Kumaravadivelu, B. Toward a Postmethod Pedagogy / B. Kumaravadivelu // TESOL Quarterly. - 2001. - Vol. 35, No. 4. - P. 537 - 560.

10. Levine, H. Vocabulary for the College-Bound Student / H. Levine. - New York : Amsco School Publications, 1965. - 399 p.

11. Lundquist, J. K. English from the Roots Up Flashcards. Help for Reading, Writing, Spelling, and S.A.T. Scores. Medina / J. K. Lundquist, J. L. Lundquist.Washington : Literacy Unlimited Publications, 2003. - 106 p.

12. Matthiesen, S. J. Essential Words for the TOEFL / S. J. Matthiesen. - M. : Barron's Educational Series, 2011. $-310 \mathrm{p}$.

13. McCarthy, M. Academic Vocabulary in Use/M. McCarthy, F. O'Dell. Cambridge : Cambridge University Press, 2008. - 176 p.

14. Короткина, И. Б. Academic Vocabulary for Social Sciences. Академическая лексика социальных дисциплин : учеб. пособие / И. Б. Короткина ; Нац. исслед. ун-т «Высшая школа экономики». - М. : Изд. дом Высшей школы экономики, 2016. -302 c.

15. Короткина, И. Б. И снова ПИУМ: жизнь интерактивных материалов в курсе по академ. лексике / И. Б. Короткина // Информационно-коммуникационные технологии в лингвистике, лингводидактике и межкультурной коммуникации: сб. ст. / под ред. А. Л. Назаренко. - М. : Унив. книга, 2012. № 5. - C.372 - 379 .

16. Короткина, И. Б. УМК «Englishfor Public Administration»: подъем по спирали развития профессиональных и академических языковых навыков / И. Б. Короткина // Материалы Всероссийской науч.-практ. конф. «Учитель, ученик, учебник». - 2011. - С. 85 - 90 . 


\section{Академическая лексика: от курса к учебнику}

\section{И. Б. Короткина}

ОАНО ВО «Московская высшая школа соииальных и экономических наук», г. Москва, Россия

Ключевые слова: академическая грамотность; академическая лексика; английский для академических целей; английский для профессиональных целей; разработка учебных материалов.

Аннотация: Академическая грамотность научного текста предполагает не только соблюдение международных требований к его построению и аргументации, но и использование академической лексики, которая составляет отдельный корпус в английском языке. Этот корпус практически весь состоит из латинско-греческих заимствований, и поскольку они имеют формальное, метафорическое значение, то научный текст порой состоит только из них, если не считать вспомогательных слов, таких как предлоги или артикли. Более того, заимствованная лексика имеет собственное словообразование за счет аффиксации. Это словообразование, не свойственное современному английскому языку, но доминирующее в русском, дает ключ к расширению словарного запаса русскоязычных студентов практически без нагрузки на память. Единственная проблема на пути к этому заключается в разработке живой, интерактивной и эффективной методики. Именно такая методика легла в основу курса, а затем учебника «Академическая лексика социальных дисциплин». В его основе лежат логические игры, анализ и синтез, использование фоновых знаний и сотрудничества. Навыки распознания и конструирования новых слов развиваются по принципу «восходящей расширяющейся спирали» и сопровождаются интерактивными слайдами. Курс апробирован в двух университетах и может быть полезен преподавателям английского языка для академических и профессиональных целей, а учебник - исследователям и студентам в самостоятельной подготовке к написанию научного или академического текста.

(C) И. Б. Короткина, 2017 